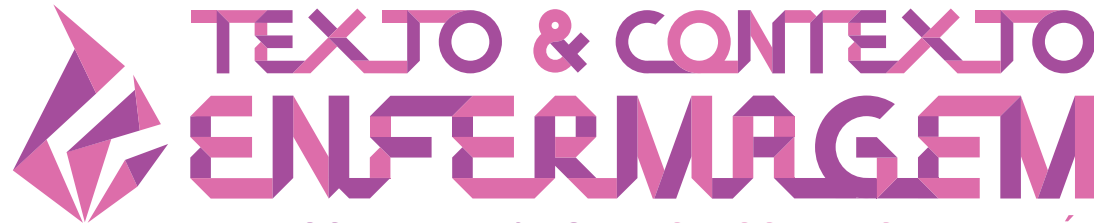

TEXT \& CONTEXT NURSING TEXTO \& CONTEXTO ENFERMERÍA

\section{PREVALENCE OF FRICTION INJURY AND ASSOCIATED FACTORS IN ELDERLY IN INTENSIVE THERAPY}

\author{
Chrystiany Plácido de Brito Vieira ${ }^{1}$ (D) \\ Patrícia de Carvalho Ferreira ${ }^{1}$ (D) \\ Telma Maria Evangelista de Araújo' ${ }^{1}$ (1) \\ Fernando José Guedes da Silva Júnior ${ }^{1}$ \\ Francisca Tereza de Galiza ${ }^{1}$ \\ Átila Sâmia Oliveira Rodrigues ${ }^{2}$ (it) \\ ${ }^{1}$ Universidade Federal do Piauí, Departamento de Enfermagem. Teresina, Piauí, Brasil. \\ 2 Universidade de Fortaleza. Fortaleza, Ceará, Brasil.
}

\begin{abstract}
Objective: to analyze the prevalence of friction injuries and associated factors in the elderly admitted to the Intensive Care Unit.

Method: a cross-sectional analytical study, developed in an Intensive Care Unit of a Teaching hospital, with a sample of 101 elderly. Data collection was conducted from November 2017 to May 2018, through interviews, consulting medical records and physical examination. For analysis, descriptive and inferential statistics were performed. Strength of associations between variables measured by odds ratio and $95 \%$ confidence intervals. Statistical significance level was set at $5 \%$ for all analyzes.

Results: the sample studied had a mean age of 71.39 years, mostly male, married and without schooling, with more than one comorbidity, dependent, with dry and scaly skin and bruising on the extremities. The prevalence of friction injury was $28.7 \%$, with an average of 1.93 injuries per elderly. There was a statistically significant association between the occurrence of friction injury with age, comorbidities, dry and scaly skin.

Conclusion: the prevalence of friction injury was high and associated with age, comorbidities, dry and scaly skin, and mean duration of corticosteroid use.
\end{abstract}

DESCRIPTORS: Wounds and injuries. Friction. Elderly. Aging of the skin. Nursing. 


\section{PREVALÊNCIA DE LESÕES POR FRICÇÃO E FATORES ASSOCIADOS EM IDOSOS EM TERAPIA INTENSIVA}

\section{RESUMO}

Objetivo: analisar a prevalência de lesões por fricção e fatores associados em idosos internados em Unidade de Terapia Intensiva.

Método: estudo transversal e analítico, desenvolvido em Unidade de Terapia Intensiva de Hospital Escola, com amostra de 101 idosos. Coleta de dados realizada de novembro de 2017 a maio de 2018, por meio de entrevista, consulta ao prontuário e exame físico. Para análise, realizou-se estatística descritiva e inferencial. Força das associações entre as variáveis aferida pelo odds-ratio e intervalos de confiança de $95 \%$. Nível de significância estatística estabelecido de $5 \%$ para todas as análises.

Resultados: a amostra estudada apresentava média de idade de 71,39 anos, maioria do sexo masculino, casados e sem escolaridade, com mais de uma comorbidade, dependentes, com pele seca e descamativa e com hematomas nas extremidades. A prevalência de lesão por fricção foi de $28,7 \%$, média de 1,93 lesões por idoso. Verificou-se associação estatisticamente significativa da ocorrência de lesão por fricção com idade, comorbidades, pele seca e descamativa.

Conclusão: a prevalência de lesão por fricção foi elevada e associada à idade, comorbidades, pele seca e descamativa e média do tempo do uso de corticoide.

DESCRITORES: Ferimentos e lesões. Friç̧ão. Idoso. Envelhecimento da pele. Enfermagem

\section{PREVALENCIA DE LESIONES POR FRICCIÓN Y FACTORES ASOCIADOS EN PERSONAS MAYORES EN TERAPIA INTENSIVA}

\section{RESUMEN}

Objetivo: analizar la prevalencia de lesiones por fricción y los factores asociados en los ancianos ingresados en la Unidad de Terapia Intensiva.

Método: estudio transversal y analítico, desarrollado en una Unidad de terapia intensiva de un hospital universitario, con una muestra de 101 ancianos. La recolección de datos se realizó de noviembre de 2017 a mayo de 2018, mediante entrevistas, consulta de registros médicos y examen físico. Para el análisis, se realizaron estadísticas descriptivas e inferenciales. Fuerza de las asociaciones entre variables medidas por odds ratio e intervalos de confianza del $95 \%$. Nivel de significación estadística establecido en $5 \%$ para todos los análisis.

Resultados: la muestra estudiada tenía una edad media de 71.39 años, en su mayoría hombres, casados y sin educación, con más de una comorbilidad, dependiente, con piel seca y con descamación y hematomas en las extremidades. La prevalencia de lesiones por fricción fue del 28,7\%, un promedio de 1,93 lesiones por ancianos. Hubo una asociación estadísticamente significativa entre la aparición de lesiones por fricción con la edad, comorbilidades, piel seca y descamación.

Conclusión: la prevalencia de lesiones por fricción fue alta y se asoció con la edad, las comorbilidades, la piel seca y con descamación, y la media del uso de corticoides.

DESCRIPTORES: Lesiones y heridas. Fricción. Ancianos. Envejecimiento de la piel. Enfermería. 


\section{INTRODUCTION}

Friction Injuries (FI) or skin tears are wounds caused by trauma, either by friction, bruising or shearing of the skin, which may lead to the appearance of partial thickness wounds, separation of the epidermis and dermis, or total separation between both underlying skin layers. ${ }^{1}$

These injuries affect the more extremes of age, but especially the elderly, mainly due to the weaknesses of the body, caused by aging, such as the thinning of skin layers. moisture, elasticity, resistance, inflammatory response, collagen production and decreased pain perception and tactile sensitivity weaknesses that increase after the age of $75 .^{2}$

According to a prevalence study, FI are more frequent than burns and pressure injuries, they do not cause serious potentials, however these injuries cause pain and can become chronic and infective, thus affecting the quality of life of the elderly person. ${ }^{3}$

Life expectancy in Brazil has increased in recent decades which has led to a greater number of elderly people who often need care through hospitalizations, which causes the problem of FI in the elderly population to be worrying. This reality has stimulated several studies on this type of wound, with the intention of systematizing care.

One systematic literature review found an injury prevalence ranging from $3.3 \%$ to $22 \%$, associated mainly with advanced age and dependence to perform basic activities of daily living. ${ }^{3}$

In Piauí, Brazil, there are no figures available for $\mathrm{Fl}$ in hospitalized patients or in intensive care units (ICU), therefore a research question appears, with a view to quantifying the magnitude of this complication in the hospital environment, especially in ICUs, since there is a lack of knowledge in the local and national literature on this theme.

Thus, it is hoped that the present investigation can contribute to the knowledge of the epidemiology of this injury in the studied service, strengthening the knowledge on the subject, and equipping nursing professionals for prevention and control actions, which will improve the care provided to the elderly patient population.

Based on these initial considerations, this study aimed to analyze the prevalence of friction injuries and associated factors in the elderly admitted to the intensive care unit.

\section{METHOD}

A cross-sectional analytical study, developed in the ICU of a teaching hospital, located in Teresina, Piauí, Brazil.

The source population were elderly in the ICU. The convenience sample consisted of 101 elderly patients admitted during the data collection period who met the inclusion criteria: 60 years of age and over and admitted to the ICU, regardless of length of stay. Cases of readmission to the unit were excluded.

The following were used for data collection: sociodemographic and clinical data form; Katz scale; and, STAR Classification System - Friction Injury. The sociodemographic variables were: date of hospitalization, hospital stay, diagnosis, age, gender, education, marital status, retirement, monthly family income, weight, height, body mass index (BMI), nutritional status, comorbidities, chemotherapy, other treatments, smoking, continuous medication use, anticoagulant use, corticosteroid use, type and number of catheters, drains and tubes, use of adhesive dressings and location, current skin conditions (bruising, bruising on the extremities, senile purpura, skin dryness and scaling, edema), history of previous FI, previous history of falls, mobility and gait (before ICU stay), visual acuity, Katz (situation before ICU stay) and presence of friction injury. If the elderly presented any FI, information about the injuries presented (amount, location, time of injury evolution, infection, skin flap and classification) was collected. 
In order to assess functional independence for the Basic Activities of Daily Living (ABVD), the Katz Scale was used which was, adapted and validated for use in Brazil. ${ }^{4}$

The lesions were classified by the STAR Classification System - Friction Injury, which includes five categories: category 1a (skin flap may be realigned to normal anatomical position and skin or flap color is not pale, opaque or darkened); category $1 \mathrm{~b}$ (skin flap may be realigned to normal anatomical position and skin or flap coloration is pale, opaque or darkened); category $2 a$ (skin flap of lesion cannot be realigned to normal anatomical position and skin or flap color is not pale, opaque or darkened); category $2 b$ (skin flap cannot be realigned to normal anatomical position and skin or flap color is pale, opaque or darkened); category 3 (skin flap is completely absent). ${ }^{5}$

Data collection was performed from November 2017 to May 2018. The elderly who met the inclusion criteria were evaluated as to the condition of answering the interview, if they did not present because of the clinical condition or artifacts/devices, the interview was performed with the patient's guardian.

The interview was conducted to collect sociodemographic and clinical data, and was scheduled according to the convenience of the elderly or guardian and the routine of the unit. The interview was complemented with information obtained through consultation of medical records (data on clinical conditions and treatment). During the interview, the Katz Scale was applied and the result recorded on the form. Afterwards, a physical examination of the elderly's skin was performed, in a cephalocaudal sense, with attention given to skin conditions, catheters and drains inserted into the skin, adhesive dressings used and the presence of FI and characteristics. If the patient had any FI, then the STAR Rating System was applied only once.

To assess nutritional status and calculate Body Mass Index (BMI), weight and height were obtained by consulting the nutritional assessment form of the institution present in the medical records. $\mathrm{BMI}$ was calculated using the $\mathrm{BMI}=$ Weight $/$ Height $^{2}$ formula and classified according to the World Health Organization (WHO) recommendation: <18.4 underweight, 18.5-24.9 normal weight, 25-30 overweight and $>30$ obese. ${ }^{6}$

Exploratory and inferential statistical analysis was performed using the Statistical Package for Social Science (SPSS), version 20.0. Quantitative variables were analyzed and presented using descriptive statistics, such as measures of central tendency and dispersion, and qualitative variables, by proportion.

First, the Kolmogorov-Smirnov test was applied to assess normality. Nonparametric distribution of data was verified. The strength of associations between variables was measured by odds ratio and $95 \%$ confidence intervals. For the comparison of means, the Mann-Whitney test was performed. The level of statistical significance was established as $5 \%$ for the analyzes.

Participants signed the Informed Consent Form. In addition, it is highlighted that the ethical precepts of Resolution 466/2012 of the National Health Council were met.

\section{RESULTS}

A total of 101 elderly people participated in the study, whose sociodemographic information can be seen in Table 1. It is found that $53(53.5 \%)$ were male, with a mean age of 71.39 years, and the majority (86.1\%). aged 60 to 79 years, 68 (67.3\%) married, $54(53.5 \%)$ without schooling, 31 $(30.7 \%)$ with family income of up to one minimum wage. 
Table 1 - Sample characterization variables of elderly patients treated at an intensive care unit of a teaching hospital. Teresina, PI, Brazil, 2018. $(n=101)$

\begin{tabular}{|c|c|c|c|c|}
\hline Variables & Minimum & Maximum & Medium & $n(\%)$ \\
\hline Age (years) & 60 & 102 & 71,39 & \\
\hline $60-79$ & & & & $87(86.1)$ \\
\hline$\geq 80$ & & & & $14(13.9)$ \\
\hline \multicolumn{5}{|l|}{ Sex } \\
\hline Male & & & & $54(53.5)$ \\
\hline Female & & & & $47(46.5)$ \\
\hline \multicolumn{5}{|l|}{ Marital status } \\
\hline Married & & & & $68(67.3)$ \\
\hline Widow & & & & $18(17.8)$ \\
\hline Single & & & & $7(6.9)$ \\
\hline Stable union & & & & $4(4.0)$ \\
\hline Divorced & & & & $4(4.0)$ \\
\hline \multicolumn{5}{|l|}{ Schooling } \\
\hline Without & & & & $54(53.5)$ \\
\hline With & & & & $47(46.5)$ \\
\hline \multicolumn{5}{|l|}{ Retirement } \\
\hline Yes & & & & 92(91.1) \\
\hline No & & & & $9(8.9)$ \\
\hline \multicolumn{5}{|c|}{$\begin{array}{l}\text { Family Income } \\
\text { (minimum salary) }\end{array}$} \\
\hline$\leq 1$ & & & & $31(30.7)$ \\
\hline$>1$ & & & & $70(69.3)$ \\
\hline
\end{tabular}

${ }^{*}$ Minimum salary $=954,00$ reals

Regarding the clinical profile, it was observed that 54 (53.5\%) of the participants were undergoing surgical treatment, with an average length of stay of 4.19 days. Regarding nutritional status, elderly with normal weight $(65.3 \%)$ predominated, followed by obese $(14.9 \%)$. It was also observed that 64 $(63.4 \%)$ had comorbidities, including hypertension in $92(91.1 \%)$ of the cases and diabetes in 37 (36.6\%). Thus, the majority (68.3\%) used continuous medication, $45(44.6 \%)$ using anticoagulant and $34(33.7 \%)$ corticosteroids. Regarding skin conditions, it is noteworthy that $55(54.5 \%)$ presented bruising on the extremities, $38(37.6 \%)$ had senile purpura and $76(75.2 \%)$ had dry and scaly skin. Most used drains (73.3\%) and adhesive dressings $(77.2 \%)$. Although $82(81.2 \%)$ of the elderly presented normal gait and 60 (59.4\%) preserved vision, 22 (21.8\%) were dependent.

Regarding the prevalence of $\mathrm{FI}$, it was found that among the 101 elderly participants, 29 had friction injuries, resulting in a prevalence of $28.7 \%(95 \% \mathrm{Cl} 28.49-28.90)$, with an average of 1.93 friction injuries per elderly, with a total of 56 friction injuries.

Table 2 shows the description of the characteristics of the presented injuries. The predominant location was in the limbs, and $46.5 \%$ in the lower limbs, without infection (98.2\%), without flap in 29 $(39.2 \%)$ of cases and viable in $22(39,2 \%)$, for this reason category 3 was the most predominant, in $52.1 \%$ of the injuries. 
Table 2 - Characterization of the lesions analyzed. Teresina, PI, Brazil, 2018. $(n=101)$

\begin{tabular}{|c|c|c|c|c|}
\hline Variables & Minimum & Maximum & Average & $n(\%)$ \\
\hline $\begin{array}{l}\text { Amount of Friction Injuries per } \\
\text { Elderly }(n=29)\end{array}$ & 1 & 6 & 1,93 & \\
\hline $1-4$ & & & & $27(93.1)$ \\
\hline$\geq 5$ & & & & $2(6.9)$ \\
\hline \multicolumn{5}{|l|}{ Localization(n=56) } \\
\hline Lower limbs & & & & $26(46.5)$ \\
\hline Upper limbs & & & & 19(33.9) \\
\hline Abdomen & & & & $7(12.5)$ \\
\hline Posterior thorax & & & & $3(5.3)$ \\
\hline Sacrum & & & & $1(1.7)$ \\
\hline \multicolumn{5}{|l|}{ Infection $(n=56)$} \\
\hline No & & & & $55(98.2)$ \\
\hline Yes & & & & $1(1.8)$ \\
\hline \multicolumn{5}{|l|}{ Skin flap $(n=56)$} \\
\hline Absent & & & & $29(52.1)$ \\
\hline Viable & & & & $22(39.2)$ \\
\hline Hematoma & & & & $2(3.5)$ \\
\hline Ischemia & & & & $2(3.5)$ \\
\hline Necrosis & & & & $1(1.7)$ \\
\hline \multicolumn{5}{|l|}{ Classification $(n=56)$} \\
\hline $1 a$ & & & & $9(16.0)$ \\
\hline $1 b$ & & & & $8(14.2)$ \\
\hline $2 a$ & & & & $2(3.5)$ \\
\hline $2 b$ & & & & $8(14.2)$ \\
\hline 3 & & & & $29(52.1)$ \\
\hline
\end{tabular}

Table 3 presents data on the association of sociodemographic and clinical variables with the prevalence of $\mathrm{FI}$. A statistically significant association with the occurrence of $\mathrm{FI}$ was found for age $(p=0.006)$, comorbidities $(p=0.028)$ and dry and scaly skin $(p=0.023)$. Elderly aged 60 to 79 years, with comorbidities and dry and scaly skin presented, respectively, 5.02; 2.89 and 2.07 times more likely to develop FI. 
Table 3 - Association of sociodemographic and clinical variables with the occurrence of friction injuries. Teresina, PI, Brazil, 2018. $(n=101)$

\begin{tabular}{|c|c|c|c|c|c|}
\hline \multirow{2}{*}{ Variables } & \multicolumn{2}{|c|}{$\begin{array}{l}\text { Occurrence of } \\
\text { friction injuries }\end{array}$} & \multirow{2}{*}{$p$-value } & \multirow{2}{*}{ OR } & \multirow{2}{*}{ Cl95\% } \\
\hline & $\begin{array}{c}\text { No } \\
n(\%)\end{array}$ & $\begin{array}{l}\text { Yes } \\
\text { n(\%) }\end{array}$ & & & \\
\hline Sex & & & $0.502^{*}$ & 0.908 & $0.382-2.159$ \\
\hline $\begin{array}{l}\text { Male } \\
\text { Female }\end{array}$ & $\begin{array}{l}38(70.4) \\
34(72.3)\end{array}$ & $\begin{array}{l}16(29.6) \\
13(27.7)\end{array}$ & & & \\
\hline Age (years) & & & $0.006^{*}$ & 5.029 & $1.484-17.041$ \\
\hline $\begin{array}{l}60-79 \\
\geq 80\end{array}$ & $\begin{array}{c}66(93.0) \\
5(7.0)\end{array}$ & $\begin{array}{l}21(72.4) \\
8(27.6)\end{array}$ & & & \\
\hline Marital situation & & & $0.256^{*}$ & 0.620 & $0.221-1.741$ \\
\hline $\begin{array}{l}\text { With } \\
\text { Without }\end{array}$ & $\begin{array}{l}50(69.4) \\
22(30.6)\end{array}$ & $\begin{array}{l}22(28.6) \\
6(21.4)\end{array}$ & & & \\
\hline Schooling & & & $0.502^{*}$ & 0.908 & $0.382-2.159$ \\
\hline $\begin{array}{l}\text { Without } \\
\text { With }\end{array}$ & $\begin{array}{l}38(52.8) \\
34(47.2)\end{array}$ & $\begin{array}{l}16(55.2) \\
13(44.8)\end{array}$ & & & \\
\hline $\begin{array}{l}\text { Income (minimum } \\
\text { salary in real) }\end{array}$ & & & $0.255^{\star}$ & 1.571 & $0.589-4.194$ \\
\hline $\begin{array}{l}\geq 1 \\
>1\end{array}$ & $\begin{array}{l}24(33.3) \\
48(66.7)\end{array}$ & $\begin{array}{c}7(24.1) \\
22(75.9)\end{array}$ & & & \\
\hline Retirement & & & $0.207^{\dagger}$ & 3.500 & $0.418-29.327$ \\
\hline $\begin{array}{l}\text { No } \\
\text { Yes }\end{array}$ & $\begin{array}{l}8(11.1) \\
64(88.9)\end{array}$ & $\begin{array}{c}1(3.4) \\
28(96.6)\end{array}$ & & & \\
\hline Diagnosis & & & $0.093^{*}$ & 2.009 & $0.821-4.913$ \\
\hline $\begin{array}{l}\text { Clinical } \\
\text { Surgical }\end{array}$ & $\begin{array}{l}37(51.4) \\
35(48.6)\end{array}$ & $\begin{array}{l}10(34.5) \\
19(65.5)\end{array}$ & & & \\
\hline Comorbidities & & & $0.028^{*}$ & 2.898 & $1.053-7.977$ \\
\hline $\begin{array}{l}\text { Yes } \\
\text { No }\end{array}$ & $\begin{array}{l}41(56.9) \\
31(43.1)\end{array}$ & $\begin{array}{c}23(79.3) \\
6(20.7)\end{array}$ & & & \\
\hline Chemotherapy & & & $0.080^{\dagger}$ & - & - \\
\hline $\begin{array}{l}\text { No } \\
\text { Yes }\end{array}$ & $\begin{array}{l}72(71.3) \\
0(0)\end{array}$ & $\begin{array}{l}27(93.1) \\
2(6.9)\end{array}$ & & & \\
\hline $\begin{array}{l}\text { Continuous use } \\
\text { medication }\end{array}$ & & & $0.100^{*}$ & 2.167 & $0.782-6.003$ \\
\hline $\begin{array}{l}\text { No } \\
\text { Yes }\end{array}$ & $\begin{array}{l}26(36.1) \\
46(63.9)\end{array}$ & $\begin{array}{c}6(20.7) \\
23(79.3)\end{array}$ & & & \\
\hline Use of Anticoagulants & & & $0.378^{*}$ & 0.789 & $0.330-1.887$ \\
\hline $\begin{array}{l}\text { No } \\
\text { Yes }\end{array}$ & $\begin{array}{l}38(52.8) \\
34(47.2)\end{array}$ & $\begin{array}{l}17(58.6) \\
12(41.4)\end{array}$ & & & \\
\hline Use of Corticoids & & & $0.079^{*}$ & 2.113 & $0.863-5.171$ \\
\hline $\begin{array}{l}\text { No } \\
\text { Yes }\end{array}$ & $\begin{array}{l}52(72.2) \\
20(27.8)\end{array}$ & $\begin{array}{l}16(55.2) \\
13(44.8)\end{array}$ & & & \\
\hline $\begin{array}{l}\text { Use of Drains or } \\
\text { catheters }\end{array}$ & & & $0.162^{*}$ & 1.976 & $0.665-5.875$ \\
\hline No & $21(29.2)$ & $5(17.2)$ & & & \\
\hline Yes & $51(70.8)$ & $24(82.8)$ & & & \\
\hline
\end{tabular}


Table 3 - Cont.

\begin{tabular}{|c|c|c|c|c|c|}
\hline \multirow{2}{*}{ Variables } & \multicolumn{2}{|c|}{$\begin{array}{l}\text { Occurrence of } \\
\text { friction injuries }\end{array}$} & \multirow{2}{*}{ p-value } & \multirow{2}{*}{ OR } & \multirow{2}{*}{ Cl95\% } \\
\hline & $\begin{array}{l}\text { No } \\
n(\%)\end{array}$ & $\begin{array}{l}\text { Yes } \\
n(\%)\end{array}$ & & & \\
\hline Use of tubes & & & $0.609^{\dagger}$ & 1.083 & $0.266-4.406$ \\
\hline $\begin{array}{l}\text { No } \\
\text { Yes }\end{array}$ & $\begin{array}{c}8(11.1) \\
64(88.9)\end{array}$ & $\begin{array}{c}3(10.3) \\
26(89.7)\end{array}$ & & & \\
\hline $\begin{array}{l}\text { Use of adhesive } \\
\text { dressings }\end{array}$ & & & $0.487^{*}$ & 1.185 & $0.415-3.387$ \\
\hline $\begin{array}{l}\text { No } \\
\text { Sim }\end{array}$ & $\begin{array}{l}17(23.6) \\
55(76.4)\end{array}$ & $\begin{array}{c}6(20.7) \\
23(79.3)\end{array}$ & & & \\
\hline Contusion & & & $0.553^{\dagger}$ & 0.607 & $0.065-5.675$ \\
\hline $\begin{array}{l}\text { No } \\
\text { Yes }\end{array}$ & $\begin{array}{c}68(94.4) \\
4(5.6)\end{array}$ & $\begin{array}{c}28(96.6) \\
1(3.4)\end{array}$ & & & \\
\hline $\begin{array}{l}\text { Bruising on the } \\
\text { extremities }\end{array}$ & & & $0.451^{*}$ & 1.164 & $0.490-2.767$ \\
\hline $\begin{array}{l}\text { No } \\
\text { Yes }\end{array}$ & $\begin{array}{l}35(48.6) \\
37(51.4)\end{array}$ & $\begin{array}{l}13(44.8) \\
16(55.2)\end{array}$ & & & \\
\hline Senile Purpura & & & $0.074^{*}$ & 2.121 & $0.876-5.136$ \\
\hline $\begin{array}{l}\text { No } \\
\text { Yes }\end{array}$ & $\begin{array}{l}50(69.4) \\
22(30.6)\end{array}$ & $\begin{array}{l}15(51.7) \\
14(48.3)\end{array}$ & & & \\
\hline Dry and scaly skin & & & $0.023^{*}$ & 2.072 & $1.151-3.733$ \\
\hline $\begin{array}{l}\text { Yes } \\
\text { No }\end{array}$ & $\begin{array}{l}60(83.3) \\
12(16.7)\end{array}$ & $\begin{array}{l}18(62.1) \\
11(37.9)\end{array}$ & & & \\
\hline Edema in extremities & & & $0.529^{*}$ & 1.071 & $0.447-2.567$ \\
\hline $\begin{array}{l}\text { No } \\
\text { Yes }\end{array}$ & $\begin{array}{l}31(43.1) \\
41(56.9)\end{array}$ & $\begin{array}{l}12(41.4) \\
17(58.6)\end{array}$ & & & \\
\hline KATZ & & & $0.547^{*}$ & 0.913 & $0.317-2.626$ \\
\hline $\begin{array}{l}\text { Independent } \\
\text { Dependent }\end{array}$ & $\begin{array}{l}56(77.8) \\
16(22.2)\end{array}$ & $\begin{array}{c}23(79.3) \\
6(20.7)\end{array}$ & & & \\
\hline Total & $72(100)$ & $29(100)$ & & & \\
\hline
\end{tabular}

${ }^{*}$ Chi-square test; $\dagger$ Fisher's exact test

Table 4 shows the data comparing the means of sociodemographic and clinical variables with the occurrence of FI. There was a statistically significant difference only in the average time of corticosteroid use $(p=0.013)$, when compared to elderly with and without $\mathrm{FI}$, and those with $\mathrm{FI}$ had a shorter average time of corticoid use. 
Table 4 - Comparison of means of sociodemographic and clinical variables with the occurrence of friction injuries. Teresina, PI, Brazil, 2018. $(n=101)$

\begin{tabular}{|c|c|c|c|}
\hline \multirow[b]{2}{*}{ Variables } & \multicolumn{2}{|c|}{ Occurrence of friction injuries } & \multirow[b]{2}{*}{ p-value* } \\
\hline & $\begin{array}{l}\mathrm{No}(\bar{x}) \\
(n=72)\end{array}$ & $\begin{array}{l}\operatorname{Yes}(\bar{x}) \\
(n=29)\end{array}$ & \\
\hline Age (years) & 70.68 & 73.17 & 0.346 \\
\hline Family income (real) & 1807.34 & 2061.34 & 0.514 \\
\hline Length of stay(days) & 4.22 & 4.10 & 0.560 \\
\hline Body mass index & 23.38 & 23.36 & 0.144 \\
\hline $\begin{array}{l}\text { Length of time using } \\
\text { Anticoagulants (days) }\end{array}$ & 54.36 & 59.34 & 0.655 \\
\hline $\begin{array}{l}\text { Length of time using } \\
\text { Corticoids (days) }\end{array}$ & 73.06 & 56.72 & 0.013 \\
\hline KATZ & 0.43 & 0.41 & 0.934 \\
\hline
\end{tabular}

* Mann-Whitney test. Statistical significance was set at $p \leq 0.05$.

\section{DISCUSSION}

Hospitalization is recognized as a risk factor to the functional decline of the elderly, and may potentiate existing functional impairment due to factors such as malnutrition and polypharmacy, as well as previous conditions such as those related to advanced age, comorbidities, lifestyle, social and family risks, among others. ${ }^{7}$

Regarding the sociodemographic profile raised by this study, an average age above 70 years old was found, which requires public policies which favor the implementation of appropriate strategies for the needs of this population. ${ }^{8}$ Elderly patients without schooling was predominant, which may cause poor health status due to poorer living habits, greater social exclusion, lower levels of information and unfavorable socioeconomic conditions for early access to health services, unfavorable conditions that consequently worsen quality of life..$^{9-10}$

The elderly participants had comorbidities, especially hypertension and diabetes. Among the diseases most related to the aging process, the most prevalent are sensory alterations, bone and muscle diseases, cardiovascular diseases and diabetes, which causes sensory alterations in the aging process, making them more susceptible to skin injuries which can be aggravated by the delayed healing of wounds due to decreased vascularization. ${ }^{11}$ In addition, aging causes changes in blood circulation and reduction of sweat and sebaceous glands, leading to disorders in thermoregulation and, consequently, dry skin. ${ }^{12}$

Regarding the hospitalized ICU population, the presence of comorbidities may increase the period of time being bed bound, leading to poor nutritional status, and are frequent causes of compromised skin integrity of the hospitalized elderly person. ${ }^{3}$

The prevalence was $28.7 \%$ and, although there are few studies in the literature to compare, it was found to be high. Research conducted in Brazil, Australia, Canada, Asia and the United States reported a prevalence of $\mathrm{FI}$ between $3.3 \%$ and $22 \%$ in hospital settings. The rate of $3.3 \%$ was in Brazil with hospitalized cancer patients. ${ }^{3}$ A study of Danish elderly showed a prevalence of $4.6 \% .{ }^{13}$

It is noteworthy that the study population consisted only of the elderly, which may also explain the high prevalence. It is known that the Fls are more prevalent among the elderly, because it derives mainly from the weaknesses of the body, such as the reduction of skin layers, its moisture reduction, elasticity and resistance, weaknesses that increase after 75 years of age..$^{714-15}$ The skin of the elderly has an epidermis with a flat interface between the epidermis and the dermis, making it less resistant to trauma due to shear forces, friction and/or dullness resulting in the separation of skin layers. ${ }^{13}$ 
Injuries were mainly identified in the lower limbs, which are usually caused when being transferred from wheelchairs or baths. ${ }^{13}$ Lower limb location is also related to bed rails ${ }^{3}$ and, in the present study, by being immobilized ICU patients, added to the lack of support through the companions, impaired cognition, presence of drains or catheters may explain the appearance of lesions in this body region.

In the present study, there was a high percentage of injuries without flap, predominating category 3, a situation similar to that found in another study. ${ }^{1}$ The evaluation and classification of the injury are important for the choice of products and therapeutic actions, especially in the case of elderly population with prolonged hospitalization which causes treatment to be more difficult. ${ }^{13}$

Regarding the factors associated with FI, in addition to advanced age, comorbidities were identified in this study such as dry and scaly skin, physiological changes inherent to aging that expose the elderly to these injuries more than any other risk group due to weakening the skin; Old age and clinical condition also expose them by increasing their susceptibility to trauma. ${ }^{14}$

Other factors are also mentioned as associated with the occurrence of this injury: dependence to perform basic activities of daily living, ${ }^{1-2}$ cognitive impairment and agitated behavior. ${ }^{1}$ Photoaging is also highlighted, as it accelerates skin aging, contributing even more to its weakening, thereby increasing the risk for $\mathrm{FI}^{15}$

A significant difference in the average time of corticosteroid use was also observed in this study, however, contrary to the literature, since the elderly with FI had the lower average of those without injury. Evidence shows that chronic use of corticosteroids can be considered a risk factor for FI due to side effects on collagen synthesis. ${ }^{14}$ It is important to highlight that it was not raised if chronic use was used, but these were elderly with other comorbidities in severe clinical conditions, causing the use this medication for a long period of time necessary.

The fact that it was performed in only one institution caused limitations to the study, however it exposes important information on the epidemiology of this injury in the studied service, strengthening the knowledge on the subject, as well as instructing nursing professionals for prevention and control actions, which may improve care for hospitalized elderly.

\section{CONCLUSION}

The studied sample consisted of elderly with more than one comorbidity, who were dependent, and presented dry and scaly skin and bruising on the extremities. The prevalence of FI was $28.7 \%$, a high prevalence associated with age, comorbidities, dry and scaly skin and mean time of corticosteroid use. Therefore, the results show that the occurrence of $\mathrm{FI}$ in hospitalized elderly patients in ICU is worrying, as in addition to the age factor, they have more serious clinical conditions that increase the possibility of this type of injury. It is suggested that more studies like this in other intensive care units are performed in order to raise the problem in hospital services, so that appropriate prevention and treatment measures are instituted. 


\section{REFERENCES}

1. Amaral AFS, Pulido KCS, Santos VLCG. Prevalence of skin tears among hospitalized patients with cancer. Rev Esc Enferm USP [Internet]. 2012 [cited 2018 Jan 14];46(Spe):44-50. Available from: http://www.scielo.br/scielo.php?script=sci_arttext\&pid=S0080-62342012000700007\&Ing $=e n \& n r m=i s o \& t \operatorname{lng}=e n$

2. LeBlanc K, Baranoski S, Holloway S, Langemo D. Validation of a New Classification System for Skin Tears. Adv Skin Wound Care [Internet]. 2013 [cited 2018 Jan 14];26(6):263-5. Available from: https://www.ncbi.nlm.nih.gov/pubmed/23685526

3. Strazzieri-Pulido KC, Peres GRP, Campanili TCGF, Santos VLCG. Skin tear prevalence and associated factors: a systematic review. Rev Esc Enferm USP [Internet]. 2015 [cited 2018 Jul 02]; 49(4):674-80. Available from: http://www.scielo.br/scielo.php?script=sci_arttext\&pid=S008062342015000400674\&lng=en

4. Lino VTS, Pereira SRM, Camacho LAB, Ribeiro Filho ST, Buksman S. Cross-cultural adaptation of the Independence in Activities of Daily Living Index (Katz Index). Cad Saúde Pública [Internet]. 2008 [cited 2018 Feb 02];24(1):103-12. Available from: http://www.scielo.br/scielo.php?script=sci_ arttext\&pid=S0102-311X2008000100010\&Ing=en

5. Strazzieri-Pulido KC, Santos VLCG, Carville K. Cultural adaptation, content validity and interrater reliability of the "STAR Skin Tear Classification System". Rev Latino-Am Enfermagem [Internet]. 2015 [cited 2018 Nov 09];23(1):155-61. Available from: http://www.scielo.br/scielo. php?script=sci_arttext\&pid=S0104-11692015000100155\&Ing=en

6. World Health Organization. BMI Classification. Global Database on Body Mass Index: Geneva(CH): World Health Organization; 2013.

7. Pereira EEB, Souza ABF, Carneiro SR, Sarges ESNF. Global functionality of hospitalized elderly. Rev Bras Geriatr Gerontol [Internet]. 2014 [cited 2018 Nov 02];17(1):165-76. Available from: http://www.scielo.br/scielo.php?script=sci_arttext\&pid=S1809-98232014000100165\&lng=en

8. Luz EP, Dallepiane LB, Kirchner RM, Silva LAA, Silva FP, Kohler J et al. Sociodemographic profile and lifestyle of the elderly population in a city in northern Rio Grande do Sul state, Brazil. Rev Bras Geriatr Gerontol [Internet]. 2014 [cited 2018 Feb 22];17(2):303-14. Available from: http:// www.scielo.br/scielo.php?script=sci_arttext\&pid=S1809-98232014000200303\&Ing=en

9. Santos TRA, Lima DM, Nakatani AYK, Pereira LV, Leal GS, Amaral RG. Medicine use by the elderly in Goiania, Midwestern Brazil. Rev Saúde Pública [Internet]. 2013 [cited 2018 Jul 02]; 47(1):94-103. Available from: http://www.scielo.br/pdf/rsp/v47n1/en_13.pdf

10. Jesus ITM de, Diniz MAA, Lanzotti RB, Orlandi FS, Pavarin SCI, Zazzetta MS. Frailty and quality of elderly living in a context of social vulnerability. Texto Contexto Enferm [Internet]. 2018 [cited 2018 Nov 04];27(4):e4300016. Available from: http://www.scielo.br/scielo.php?script=sci_ arttext\&pid=S0104-07072018000400315\&lng=pt\&nrm=iso\&tlng=en

11. Vieira CPB, Sá M, Madeira MZA, Luz MHBA. Characterization and risk factors for pressure ulcers in the hospitalized elderly. Rev Rene [Internet]. 2014 [cited 2018 Jul 02]; 15(4):650. Available from: http://periodicos.ufc.br/rene/article/view/4912/3613

12. Bermark S, Wahlers B, Gerber AL, Philipsen PA, Skiveren J. Prevalence of skin tears in the extremities in inpatients at a hospital in Denmark. Int Wound J [Internet]. 2018 [cited 2018 Jul 23];15(2):212-7. Available from: https://www.ncbi.nlm.nih.gov/pubmed/29464916

13. Benevides JP, Coutinho JFV, Santos MCL, Oliveira MJA, Vasconcelos FF. Clinical evaluation of leg ulcers in elderly patients. Rev Rene [Internet]. 2012 [cited 2018 Jul 23];13(2):300-8. Available from: http://periodicos.ufc.br/rene/article/view/3916/3110 
14. Leblanc K, Baranoski S. Skin tear Consensus Panel Members. Skin tears: state of the science consensus statements for the prevention, prediction, assessment, and treatment of skin. Adv Skin Wound Care [Internet]. 2011 [cited 2018 Jul 23];24(9):2-15. Available from: https://www. ncbi.nlm.nih.gov/pubmed/21876389

15. Koyano Y, Nakagami G, lizaka S, Minematsu T, Noguchi H, Tamai $N$ et al. Exploring the prevalence of skin tears and skin properties related to skin tears in elderly patients at a long-term medical facility in Japan. Int Wound J [Internet]. 2016 [cited 2018 Jul 23];13(2):189-97. Available from: https://www.ncbi.nlm.nih.gov/pubmed/24674027 


\section{NOTES}

\section{CONTRIBUTION OF AUTHORITY}

Study design: Vieira CPB, Ferreira PC, Araújo TME.

Data collection: Vieira CPB, Ferreira PC.

Analysis and interpretation of the data: Vieira CPB, Ferreira PC, Araújo TME, Silva Júnior FJG, Galicia FT, Rodrigues ASO.

Discussion of results: Vieira CPB, Ferreira PC, Araújo TME, Silva Junior FJG, Galicia FT, Rodrigues ASO.

Writing and / or critical review of the content: Vieira CPB, Ferreira PC, Araújo TME, Silva Júnior FJG, Galicia FT, Rodrigues ASO.

Revision and final approval of the final version: Vieira CPB, Ferreira PC, Araújo TME, Junior Silva FJG, Galicia FT, Rodrigues ASO.

\section{ACKNOWLEDGMENT}

To the State of Piauí Research Support Foundation (FAPEPI) in the publication.

\section{APPROVAL OF ETHICS COMMITTEE IN RESEARCH}

Approved by the Research Ethics Committee of the Universidade Federal do Piauí, opinion $\mathrm{n}^{\circ} 2.085 .462$ and CAAE 68653517.1.0000.5214.

\section{CONFLICT OF INTERESTS}

There is no conflict of interest.

\section{HISTORICAL}

Received: February 4, 2019.

Approved: June 10, 2019.

\section{CORRESPONDING AUTHOR}

Chrystiany Placido de Brito Vieira

chrystianyplacido@yahoo.com 